\title{
GUDERNES RUM OG MENNESKENES UNIVERS - i de mayatalende lakandoneres verdenssyn
}

I lakandonernes myter kan vi finde de grundelementer, som gør det muligt for os at forstå den særlige opfattelse, disse indianere har gjort sig af rummet og tiden. Ved mentalt at genskabe sig universets oprindelse danner de sig et billede af, hvorledes de tre rum, som er nødvendige for den kosmiske ligevægt, er indrettede og beskafne. For det er solens gang fra det ene til det andet af disse rum, som sikrer, at livsprincippet består, at samfundet af Sande Mennesker ${ }^{1}$ reproduceres.

Opdelingen af universet i tre, et himmelsk, jordisk og underjordisk, rum tillader en bestemmelse af det rumlige domæne for menneskers handlen - i midten, følgelig på jorden - og samtidig en bestemmelse af dette rums tidslige grænser. Deres guder har anbragt dem i hjertet af et rum af skov, som blev skabt netop for dem. Derfor anskuer lakandonerne deres egen eksistens som en fase i solens liv, som de er nået til, efter de dukkede frem af ktoniske rum, og før de skal vende tilbage til de samme steder efter døden.

Demiurgerne skabte disse rum og opnåede derved at skabe orden i principperne for menneskets vilkår. Med hjemsted i centrum af et univers, på en jord, som blev dem betroet, er lakandonerne vidner til solens daglige bevægelse fra deres skovs ene horisont til den anden, ad en bane, der leder den fra zenit til de dødes egne, hvorfra den atter vil dukke frem for at sikre verdens og menneskers overlevelse. Solen forbinder disse tre rum i løbet af årets dage og det er derigennem, den fuldfører sin genskabelsesopgave. Deri bliver den bistået af menneskene, der med deres ofringer nærer guder og stjerner.

Parret sol-måne tager vare på livet, men det udgør også en trussel om død. Lakandonerne ved fra myterne, at deres univers tre gange tilforn er blevet omstyrtet, deres skov oversvømmet eller brændt bort, deres forfædre sønderflænget, deres historie brudt af førend samfundet atter kunne genfødes, nu underlagt andre uordner og underkastet andre truende magter.

Tider og rum flettes sammen i lakandonernes tænkning. Men først efter der var skabt rum, kunne tidens orden dannes ved stjernernes bevægelsesbane. Systemets regelmæssighed, ligevægten mellem livets og dødens principper, som er underlagt stjernernes vekslen, kunne kun bringes til veje i kraft af menneskenes vedvarende anstrengelse for at tilfredsstille betingelserne for stjernernes gendannelse. Kun ved rituelt at skaffe guderne næring lykkedes det mayaerne - og før dem alle mellemamerikanske kulturer - at opretholde orden i kosmos. 
Disse kulturer giver således udtryk for de smertelige anstrengelser, menneskene må gøre sig for at sikre, at rummet og tiden fortsat gendannes. Adskillelsen af himmelske og jordiske rum, af solens og månens principper, af lysets og mørkets faser, danner sikringen af himmellegemesystemets stabilitet. Menneskene er ansvarlige for denne skrøbelige orden, og deres ritualer giver dem muligheden for at udøve den regulerende indvirkning på universets ligevægt. Kun i kraft af menneskets kultur sikres orden i kosmos og, at naturen tilvejebringer samfundet de ressourcer, som behøves for dets velfærd.

\section{Symbolske forestillinger om solen}

Ifølge de nordlige lakandoneres mytologi blev solen, K'in, skabt af Hach Ak Yum, ${ }^{2}$ og indianerne forestiller sig ham som en meget hvid mand, hvis hoved udstråler et livgivende lys - det selvsamme som oplyser månen. Han er ude af stand til at forblive i en ubevægelig tilstand og gennemløber himmelbuen fra øst til vest, fra daggry til skumring. Han hviler under jorden, hvor han styrker sig, før han genoptager sin gang. ${ }^{3}$

I en myte fra den sydlige gruppe ${ }^{4}$ nævnes en person, kaldet Känän Beh K'in (solens vejs vogter), som det var blevet pålagt at nære solen under dens rejse om dagen. Hver dag steg han op til zenitpunktet for at give solen styrke, midtvejs på dens bane. Denne sælsomme figur (som alene omtales i denne tekst) lader sig ledsage af en sjældent skræmmende, tohovedet jaguar, for den besad evnen til ,,at fordoble sig selv, til at dele sig i to“", når den tog sig for at overfalde de Sande Mennesker, som vovede sig op på ,solens vej“. Uden tvivl drejer det sig om forestillingen om himmeljaguarer, der er i stand til at destruere verden under en solformørkelse. ${ }^{5}$

Sydlakandonerne identificerer solen som K'in Ich Ahau (Herre med solansigtet). ${ }^{6}$ Han er den anden af tre brødre, og han modsvarer derfor guden Ah Kyantho hos nordlakandonerne. Der består en dobbelt relation mellem Hach Ak Yum og hans ældre broder Ah Kyantho både i kraft af, at de er helbrødre, og har en fælles hustru, Ak Na'. ${ }^{7}$ Ved sin forening med Ah Kyantho-K'in Ich Ahau reproducerer Ak Na' tydeligt de to store himmellegemers anlæg for opposition-komplementaritet, og bekræfter atter de dualistiske organisationsprincipper i det samfund, hun har frembragt. Omvendt definerer de tre brødre i kraft af det søskendeprincip, som forener dem, universets tre rum, samtidig med at de reproducerer tidens gang: himmelguden Ik Chan Yum modstilles Zukunkyum, den underjordiske verdens Herre, medens K'in Ich Ahau drager igennem hvert af de rum, hvor hans brødre hersker, ved både at forene sig med jorden og fjerne sig bort fra den ved gry og skumring.

I dagligdagens univers behersker mændene før-middag-rummet; de sikrer med deres arbejdsindsats gruppens reproduktion. Kvinderne trækker sig da tilbage i det huslige rum, da de er udelukket fra mandlige gøremål. Om eftermiddagen varetager mænd og kvinder sammen forskellige opgaver: de mødes i svedjerydningen eller familieværkstedet for at udføre de ting, der kræver samarbejde af alle. Natten er kvindetid, hvor de under månens tegn udnytter rummet for den huslige autoritet, som betrygger den sociale orden. Manden rejser lige som solen, hvis symbolske udtryk i menneskesamfundet han er, i jordens dybder for at befrugte kvinden, månens symbol, som sikrer artens reproduktion. Hver aften dykker solen ned i mørkets rige, hvor han befrugter jorden, og hvorfra han atter stiger op i morgengryet. Og efter en lang rejse generobrer den sin plads i 
zenit som symbol på lysets sejr over mørket. Ganske som solen, der drager ud, dykker ned i døden og genfødes af mørket, søger manden den evige tilbagekomst.

\title{
Symbolske forestillinger om vinden og vandet: regnens guddomme
}

Både regnfaldenes oprindelse og deres fordeling ud over årstiderne har lakandonerne beskrevet i en meget smuk fortælling, som Boremanse har publiceret (1986:54-56). ${ }^{8} \mathrm{Vi}$ vil citere enkelte uddrag, som på en tydelig måde viser, hvorledes disse indianere forestiller og forklarer sig de meteorologiske fænomener i løbet af solåret.

\begin{abstract}
Mensabäk er en gud, der levede i en grotte på en søbred. Han brændte kopal og fangede denne røgelses røg i en terrakottakrukke. Så kradsede han lidt på den, og ud af den slap noget vældigt sort [...] Han tog en papegøjehale, en arahale, og han smurte soden ud over den. Han spredte halen i luften og rystede dens arafjer. Soden, røgelsesrøgen, dannede skyerne. Og sodmageren sang sin sang [...] Så fordelte han soden mellem Vandguderne. Han gav noget til „Nord“, han gav noget til „Nordøst“, han gav noget til „Oversvømmelsenhvorfra solen-kommer", han gav noget til „Vestguden“, han gav noget til „Sydvest“. Han gav ikke noget til „Syd“, for det er en tør, regnløs vind. „Syd“ sender skyer tilbage til „Nord“ “ [...] Alle regnstrømme må søges hos Mensabäk. Det er Ah K'in Chob som beder om dem på Hach Ak Yums vegne. Han kommer med en lille flaskekalabas (som mål) [...] - Har du sod, så tørtiden kan få ende hos jordboerne? [...]

Ah K'in Chob drager bort med sin lille flaske, fuld af sod, for at finde Vandguderne. De lever i underjordiske huler, under klipperne i skoven. Talrige er de. Ah K'in Chob deler soden ud imellem dem.

- Herrer, her er efter Vor Faders ord netop det, der kan få tørtiden til at slutte; her er det, der får blomsterne på poukté-træe t ${ }^{9}$ til at springe ud, og dem på onté-træet; ${ }^{10}$ her er det, der får floder og søer til at gå over deres bredder ${ }^{11}$ - til hver tid sit mål. Og her til vindene fra nord [...] Og Vandmenneskene skabte regnen og sendte den mod jorden (de rejste på himlen) [...] $\mathrm{H} ø \mathrm{r}$ her, hvordan de gør torden. De ryster arahalen og synger deres sang for den. Med vifteslag slår de [...] Dum, bum! De ryster arahalen og får skymasser til at rejse sig. Derfor slår de luften med viften, for at få skyer til at rejse sig og tordenen til at genlyde. Dum, bum! Regnguderne har en grøn økse, med den kan de frembringe lyn. Når de får øje på en dæmon i skoven, løfter denne sin tunika og viser dem sin bagdel, mens den råber:

- Se min røv, se min røv!

Så bliver Regnguderne vrede og slår dæmonen med deres grønne økse. Det er lynet. Hvis dæmonen søger tilflugt i et hult træ, kaster Regnguderne deres økse oppefra, og lynstrålen rammer ned på træet. Det er sådan, de frembringer lyn og torden, vind og regn. Det hænder, de efter et voldsomt regnfald lader den lange arahale med dens smukke fjer trække hen over himlen, og deraf kommer regnbuen. Hvad betræffer haglen, er det Hach Ak Yum, der lader sin svigersøn søge den hos Itzanohk'uh.
\end{abstract}

Vigtigt er det at få belyst, hvorfra disse mytiske personer, som forbindes med vinde, regnfald og skyer, stammer, og hvorledes de knytter sig til verdens kvindelige principper ved regnstrømmenes komme. De „Røde Drenge“, vind- og uvejrsbringerne, er skaberens tre ældste sønner. De blev forstødt fra himlen, da de engang gjorde oprør mod deres faders magt og forsøgte at dræbe deres yngre bror, T’uup, og derfor blev de dømt til at tage ophold på jorden, hvor deres opgave består $\mathrm{i}$ at fordele vind og regnvand. Man finder dem kun i nordlakandonernes mytologi, dog har figuren Wayantekob hos sydlakandonerne optaget visse af deres træk. Da de forbindes med regn-og i deres Wayantekob-træk-med 
døden, står de i nær tilknytning til Mensabäk, ${ }^{12}$ men også til X-K'ale'ox/Ak Na', da de jo er hendes sønner. I kraft af deres navn, Chäk Xib, er de tæt forbundet med den røde farve, som karakteriserer dem. Nu er et af de udmærkende træk ved den gamle, førspanske mayagudinde Ix Chebel Yax - som er gift med skaberguden Itzam Na' ${ }^{13}$ - netop sammenknytningen med farven rød, da hun har til opgave sammen med sin mand at oversvømme jorden. ${ }^{14}$ Men ved et andet træk forbindes denne mangefacetterede gudinde, under navnet Ixchel, med vævning og børnefødsler og ledsages da af farven hvid. I Chilam Balam fra Chumayal ${ }^{15}$ forbindes hun også med fødemidler, især majs, under navnet Cab (Jordens herskerinde); hos lakandonerne forbindes hun med brødtræe ${ }^{16} \mathrm{i}$ kraft af den ceremonielle term X-K'ale'ox (Vor frue brødtræets gule løv). ${ }^{17}$ Når hun forbindes med sine sønner, de tre Røde Drenge, knyttes hun til regnfald og vinde, og som den yukatekiske månegudinde Ixchel beskrives hun også som høvding over Chac'erne: den efterklassiske og nutidige mayamytologis vind- og regnånder. Lopez de Cogolludo ${ }^{18}$ præciserer, at hun dér forbindes med Chac'en i syd. I mayakosmologien repræsenteres syden af farven gul, og dertil er X-K'ale'ox jo knyttet i kraft af sit navn. I Dresdenkodeksen forbindes hun også med regnstrømmene og farven gul og omgives altid af Chac'er: vandstrømme synes at sprudle frem fra deres spredte ben eller fra kar, de udøser over jordsmonnet.

En ch'ol-myte fra Palenqueområdet beretter om en mand ved navn Chahc. Han sender en af sine tjenere hjem til sig, for at denne kan bede Chahcs hustru om at væve sin mand et klæde. Parrets børn er frøer, som er sat til at vogte huset. Chahcs hustru spinder meget bomuld, og dette bliver de skyer, hvormed Chahc kan kontrollere og sende regnfaldene. ${ }^{19}$ Her har vi en slående analogi mellem regnguddommens hustru, bomuld og de vandbærende skyer, hvilket understreger homologien mellem en kvindelig vandguddom og månegudinden.

Hvis nu disse arkæologiske og etnografiske detaljer synes at bekræfte forbindelsen mellem X-K'ale'ox (yukatekisk: X-Kan Le Ox) og Chac-figurerne, og det vil sige med regnens oprindelse, så vil en sammenligning mellem dem og lakandonmyten ikke desto mindre, ud over visse analogier, lade en række tvetydigheder træde frem.

$\mathrm{X}-\mathrm{K}$ 'ale'ox og hendes sønner forbindes med rød, fordi de som ansvarlige for himmelvandene også forbindes med øst og med livet: farven rød repræsenterer solens tilbagekomst til verden i øst. ${ }^{20}$ I myten om regnfaldene deler Mensabäk soden ud mellem sine hjælpere, for at de skal fordele de vandbringende vinde ud over skoven. Men syden får ingen sod. Faktisk siges det, at Syd ,er en regnløs, tør vind. „Syd“ sender sine vinde til „Nord“..." Nu er Nord jo forbundet med hvid, og ifølge Thompson er hvid (zac) den anden farve som tilskrives månegudinden i hendes egenskab af herskerinde over vævning (zacal: at væve). ${ }^{21}$ Uden tvivl peges der her på månegudindens dobbelte personlighed: hun er både skaberens hustru (hvid, vævning, børnefødsler) og moder og høvding for vindbringerne (gul, tør vind, død). Dette vind-fra-syd-træk, tørhedens vind og derfor døden, synes altså at tilskrive denne mangefacetterede gudinde uheldsvangre og dødbringende egenskaber.

En passage i Chilam Balam fra Chumayel understreger faktisk denne sammenknytning af månen med farven hvid, regnfald og bomuld:

Månen var omgivet af hvide regnkredse. Himlene fyldtes med regn; regnskyl genlød i himlene; himlene blev stormet af regnfald, af himmelske regnfald, af himmelske regne af bomuld $[\ldots]^{22}$ 
Vinde og regnfald kan skiftevis være livets eller dødens vektorer, alt efter heftigheden, hvormed de raser, eller tidsrummet, hvori de viser sig. Derved reproduceres den dikotome fordeling af egenskaber, som tilskrives de guddomme, der kontrollerer de klimatiske fænomener, samtidig med at de skiller året i de tidscykler, der skanderer årstidernes vekslen: „Til hver tid sit mål““.

Den sod, Mensabäk deler ud af, er en røgelsesrøg, og det er fra denne røg - fra denne tåge, der breder sig ud mellem himmel og jord - at regnen vil strømme. Mens vindene er „formidlere af tiden“ ${ }^{\prime 23}$, fremtræder tågens røgdannelser som ,formidlere af rummet" ${ }^{\text {"24 }}$ for de adskiller menneskene, der modtager vejrligets velgerninger, fra guderne, der skænker dem. Men kan tågen skille ad, kan den også forbinde: ${ }^{25}$ derfor aflægger de Røde Drenge besøg hos deres slægtninge ved ,,at brænde en vej“ til himlen og skaber dertil regnbuen, der danner en skrøbelig forbindelse mellem fugtigheden fra den jord, de har badet i regn, og varmen fra den sol, de nærmer sig.

Som moder til vindbringerne (hos lakandonerne) og høvding for regnbringerne (i størstedelen af de andre mayakulture ${ }^{26}$ ) indlejrer månegudinden et kvindeligt princip centralt i de symbolske forestillingen om regnen. Selvom der i den lakandonske myte (i Boremanses oversættelse) henvises til ,,vandguder“, som alle er Mensabäks hjælpere, må disse figurer - lige som Chac'erne blandt andre mayaer - forbindes med vandets kvindelige og ktoniske principper.

\section{Økologi og slægtskab}

Lakandonmytologien er præget af den snævre sammenhæng, der består mellem universets og samfundets orden: de meteorologiske, økologiske og altomfattende kosmiske fænomener begribes og fortolkes ud fra de modeller, der forklarer og regulerer slægtskabsrelationerne. Når menneskesamfundet genopfører gudesamfundet, ${ }^{27}$ og når hver af disse guddomme er pålagt en særlig opgave i de klimatiske fasers virkemåde og de meteorologiske fænomeners fremkomstrytmer, bliver det tydeligt, at vi har at gøre med eksistensen af et kosmologisk system, i hvis midte mennesket spiller en betydningsfuld rolle - en rolle, der er komplementær til gudernes, og hvis logik er indskrevet i den familiemæssige ansvarsfordeling og slægtskabssystemet.

Skaberens familie er mere end blot en model af den sociale organisation. Netop ved at hvert af dens medlemmer knyttes sammen med naturfænomener, ${ }^{28}$ er det den, der sikrer de klimatiske kredsløbs gentagelse, og derved angiver den over for menneskene, hvorledes disse bør forvalte det sociale rum, den sociale tid, nemlig i overensstemmelse med det ansvar, hvert enkelt af dem har fået at varetage. Det er ved at afkode dette tilknytningssystem, vi får mulighed for at forstå, hvorledes lakandonerne opfatter den parallelisme, som består mellem samfundets og universets orden.

Hach Ak Yum står for den højeste autoritet, for han har skabt solen. Hos befolkningen ved Lacanjàfloden er han solens yngre broder, og i en kekchi-myte identificeres han selv med solen. ${ }^{29}$ Skaberen har fem børn. Hans tre første sønner - regnfaldene og tordenvejrenes vinde - danner regnbuen og bliver på denne måde de forbindende størrelser mellem himlens og jordens rum, samtidig med at de udgør vejrperiodernes adskillende størrelser. Berøvet deres ældrerettigheder, skifter de til en status som yngre: de fortaber deres plads i himlen ved siden af faderen og bliver knyttet sammen med verdens kvindelige side, regn- 
faldene. Deres moder, X-K'ale'ox, udgør regnens fjerde princip, og skal man tro de forskellige versioner af myten om regnfaldenes oprindelse, er hun også deres høvding. Hun er knyttet til månen og kompletterer som sådan solen i løbet af agerbrugscyklens vejrligsfaser.

Hach Ak Yums yngre datter har fra sin moder arvet en forbindelse med månen. Af og til identificeres hun som Ixchel, det vil sige som hustru til Ah K'in Chob, der jo selv er en guddom med solegenskaber. Skaberparrets yngste søn, Ah T'uup,,$^{30}$ er solens beskytter; han har arvet symbolerne på mandlig autoritet (de rituelle sange), og det er derfor ham, der drager omsorg for solens genkomst og årstidernes vekslen. Lakandonerne påkalder ham i særlig grad ved solformørkelser. Også Hach Ak Yums to ældre brødre forbindes med solen: Zukunkyum, fordi han er dens beskytter i den underjordiske verden, og Ah Kyantho, fordi han knyttes sammen med den i den sydlige lakandongruppes mytologi.

Når vi ser bort fra de tre faldne brødre, der tilskrives kvindelige egenskaber og optræder underlagt en kvindes (deres moders) kontrol, kan alle mandsfigurerne i denne familieenhed sættes i forbindelse med solen - gennem helbroderskab (Zukunkyum), afstamning (T'uup) eller ægteskabsalliance (Ah K'in Chob) er de alle ansvarlige for dens bane eller dens ernæring.

Omvendt har kvinderne herredømmet over månens rum og den våde årstid. De mænd, der har mistet deres ældrerettigheder, sættes netop i forbindelse med kvinder, både hvad angår tiden (regntiden) og de rum (grotter og huler), som kendetegner dem.

Komplementariteten mellem de væsner, der danner famelieenheden - forbundet med de hierarkiprincipper, som giver enheden sammenhængskraft - udgør grundlaget for den sociale orden, men også betingelserne for den universelle orden. Og disse udmærkende træk har lakandonmyterne hentet i slægtskabssystemet, samtidig med at de forlener de selvsamme træk med bestandighed og legitimitet.

\section{Oppositions-, alternans- og komplementaritetsprincipper}

På baggrund af denne fremlæggelse af etnografiske oplysninger, analyse af myter, og beskrivelse af menneske- og plantelivets store faser, fremtræder der, imellem komponenterne i det sociale univers, en serie oppositioner, som vi kan genfinde i selve naturens organisationssystem. Og de vidner om, hvorledes samfundet og kosmos begribes i en dualistisk form. Den kan sammenfattes på denne måde:

$$
\begin{aligned}
& \text { Mænd : kvinder :: Ældre : yngre } \\
& \text { Sol : Måne :: Tørke : regn }
\end{aligned}
$$

Ud fra disse primære homologirelationer danner der sig en hel kæde af oppositioner, som tydeligere præciserer de associationsforbindelser, hvormed lakandonerne fortolkende opfatter deres univers. 


\section{Akserne øst-vest og nord-syd}

Solen gennemløber verden fra øst til vest, og disse kardinalpunkter bliver derfor til udtryk for liv og død (rød: livet i øst; sort: døden i vest). Månen sættes i forbindelse med syd og nord, og den tilskrives selv egenskaber, der er særkender ved netop disse horisonter (gul: varmen i syd; hvid: kulden i nord). ${ }^{31}$ Medens forbindelsen mellem solhimmellegemet og aksen opgang-nedgang kan afdækkes i samtlige tekster, der refererer til kosmisk orden, ${ }^{32}$ er månehimmellegemets forbindelse til nord-syd-aksen mere hypotetisk - selvom den findes i hovedparten af nutidige og gamle, mellemamerikanske kulturer-fordi den findes $\mathrm{i}$ en ofte indirekte, tilsløret form. Vi har allerede bemærket forbindelsen mellem XK'ale'ox og både tørtidens vinde og de regnmættede vinde fra nord, men denne forbindelse må findes i allegoriske udtryk, som kun det esoteriske sprog er i stand til at oversætte. Myten udgør faktisk ,ikke en homogen diskurs, fordi den i sine forskellige dele kan være mere eller mindre farvet af symbolisme og udvise forskellige grader er esoteriskhed “" ${ }^{33}$

Inden for denne opposition mellem paradigmatiske enheder finder vi atter andre oppositioner, nemlig inden for de par, som udgør modstillingernes skelet. Således kan månen også forbindes med solnedgangen, da den hersker over de marginale rum. På den anden side fremviser hvert enkelt af disse paradigmatiske par også selv en model af kosmologisk og økologisk dualisme. Således gælder det, at mens vindene fra øst, der jo opstår på golfkysten, er gunstige for liv og tunge af frugtbarhedsbringende vand, fører de vinde, der stammer fra vest, ikke andet end uorden med sig - de vælter og knækker planter og ledsages ikke altid af velgørende regnvejr. Mens de tørre og varme vinde fra syd ikke medfører andet end vandløs stormstødsblæst og derfor anses for at være neutrale vinde, uden indvirkning på de Sande Menneskers liv, regnes de fugtige og isnende vinde fra nord for budbringere om kulde, der med sig bærer hagl og sygdomme, og derfor betragtes de som såre uheldssvangre både for menneskers og vinterhøstes overlevelse. Mens altså det solare princip kun øver indflydelse langs øst-vest-rummet, knyttes det lunare princip både til samme akse (i vest) og dominerer alene nord-syd-rummet ved i sig at samle dette rums mangfoldige træk (velgørende-skadelig, varm-kold, tør-fugtig osv.).

\section{Nomadisk og sedentær}

Solen bevæger sig; uden rast gennemvandrer han himmelske og underjordiske rum. Som en utrættelig rejsende drager han gennem menneskenes og himmelhvælvingens skov, før han gennems $ø$ ger dén i underverdenen. I lakandonsamfundet - der karakteriseres ved patriuksorilokal residens - forlader manden, efter solens eksempel, sin faders hus, når han skal indgå ægteskab og selv grundlægge et ildsted. Til daglig drager også han, sammen med sine sønner eller brødre, sine svigersønner eller svogre, gennem skoven og indfinder sig kun på det sted, han bor, for der at indtage sine måltider og gøre sin hustru frugtbar.

Modsat ham, er Månen autokton; hun er sedentær og hendes bevægelser på himmelbuen er begrænsede. Hun kommer frem og forsvinder ifølge sine faser, hvor hun tager til i vækst og flygter bort til de småøer i søer og floder, hvor hun har valgt at bo. ${ }^{34}$ Anskuet efter denne model, knytter også kvinden sig stærkt til sit fødested. Hun drager manden til sin verden og holder ham fast i sit land. Matrilokalitet er et kvindeprivilegium i overensstemmelse med det autoktoniprincip, der forbindes med Månens person. ${ }^{35}$ Det er de 
autoktone kvinder fra Lacanjàfloden, for hvem det lykkedes at samle de mænd fra forskellige familier, som fordums levede spredt. Og det er over kvinderne, de rettigheder til autoktoniadgang går, som gør, at deres børn bliver deres bedstefædres ligemænd. Denne beskrivelse af det sociale system er stik modsat den, myterne udtrykker, for i disse gøres de autoktone til de ældre, og nomaderne til de yngre. De gamle (toltekiske og aztekiske) myter fremhæver dette udtryk for mellemamerikansk tankegang, når de forbinder de nyankomne mexica med vilde-nomader-fattige-yngre, som havde held til underkaste sig de civiliserede-fastboende-rige-ældre. ${ }^{36}$ Men hvorfor betragtes de sedentære, autoktone kvinder i nutidens samfund som yngre, og hvorfor giver lakandonerne mændene og deres efterkommere ældrestatus? Denne mandlige magt, som mænd så grådigt har kæmpet med kvinder om og så kostbart har vundet, og som vi finder dybt indlejret i slægtskabsterminologien - repræsenterer den ikke de yderste anstrengelser, som mændene må gøre for til egen fordel at forvandle en samfundsorden, som unddrager sig dem, fordi det er en orden, der har været underlagt kvindelige principper fra tidernes morgen og stadig vil være det til tidernes ende og opløsning?

Om dette tema har Galinier ${ }^{37}$ i sin analyse af otomi-samfundet understreget, at ,kvinderne sidder inde med kontrollen over de overnaturlige kræfter. De er Verdens Herre [...] og samler i sig universets hele rigdom [...] Denne overmagt belaster faretruende samfundets, den kommunitære ordens, sammenhængsevne, som mændene er garanter for". Mens mændene forsøger at fastholde den reelle magt, har kvinderne eneret på den egentlige magt. Og det er den systematiske udnyttelse af dualismen (og dens antropologiske og kosmiske aspekter ${ }^{38}$ ), som muliggør netop denne logik i de sociale relationer, og da især i relationen mand-kvinde.

\section{En og mange}

Solen er udelelig; den fødes, dør og lever atter op, men den er altid samme himmellegeme såvel i sin daglige fase som under sit liv om natten. En kekchi-myte ${ }^{39}$ omtaler eksistensen af en aftensol, som blot skulle være et spejlbillede af den selv, men hvad enten den gengives i et spejl eller i sin virkelige fremtrædelse, forbliver den det samme himmellegeme, som utrætteligt gennemstrejfer universets rum.

Omvendt er månen mangeartet, både i kraft af sine egenskaber og de steder, hvor den finder hvile. Allerede dens fire faser forlener den med et træk af mangfoldighed og omskiftelighed, som solen ikke har. Snart tiltagende, snart aftagende eller fuld ændrer den udseende og egenskaber på samme tid. Den er frugtbar eller svanger, når den er fuld, den er gold, når den er i næ, og den er faretruende under en formørkelse. Den tager skikkelse af mange i den underjordiske verden, hvor den optræder som X-Tabay'er, dens jordiske og underjordiske figurer, og som menneskenes moder, bliver den deres ledsager. Månen er én på himlen (om end i forskellige fremtrædelser), men den kan også gøre sig til mange, når den tager ophold på småøer, i grotter og i de store kapoktræer. Men den er frem for alt mangefacetteret i egenskaber, magt, i sine gaver og indsigter: herre over barnefødsler, men også over kure mod sygdom, ulykker og drømme. ${ }^{40}$ Månen er hersker over liv og død, men knyttes også sammen med planternes vækst og de regnstrømme, der giver dem væde, med skumring og daggry, med livets morgenstund og dets forfald. 


\section{Lys og mørke}

Solens verden er lysets, derfor også det offentliges og dagens. Det er samtidig mændenes rum - domænet for deres sammentræf, forsamlinger og beslutninger. Solen er symbolet på den mandlige, officielle og nedarvede autoritet. Månens rum, der knytter sig til mørket, til grotters dunkelhed og ildstedets halvskygge, er billedet på det private, på møder mellem kvinder, på de aftaler, sådanne møder kan foranledige, og på de strategier, der dér kan lægges. Det er det hemmeliges, det skjultes og det dulgtes verden, hvor indflydelser kan gøres gældende bag om det officielle: billedet på en splittet magt, som kvinderne lige som deres moder må væve sammen for utrætteligt at genskabe samfundets grundlag.

\section{Himmelsk og ktonisk}

Dog forhindrer dikotomien ikke, at de principper, den stiller op mod hinanden, kan veksle med hinanden. De dualistiske kendetegn, som lakandonerne anvender for at gøre sig universet forståeligt og for at regulere deres eget samfundsliv, gør andet og mere end at opstille modsætningerne. De understreger også, at der findes en ordnet række af faser, perioder eller egenskaber, som synes at udelukke hinanden i kraft af deres tilsyneladende uforenelighed. Men det er jo også sådan, at solen indtager zenit, før den dykker ned i den underjordiske verden, og derved lader den månen beherske nattehimlen. $\mathrm{Og}$ i sine ktoniske aspekter er månehimmellegemet også en underverdensbeboer, der bytter plads med solen som synlig for menneskers blik. I sit regnaspekt følger Månen Solen, kompletterer den ved at tage dens plads.

\section{Majs:maniok::myre:slange}

Vi genfinder dette komplementaritetsprincip i plante- og dyrekategorierne. Kornplanterne, især majs, knyttes til solen og dens komme. I ch'ol-skabelsesmyten var det et ildlyn, der frigjorde majsen fra dens underjordiske tilholdssted: efter i lang tid at have været indespærret i jordmørket, så majsen dagslys, da ildstjernen blev sat på sin plads af skaberen. Majsen havde altså del i verdens ktoniske principper, før den blev draget frem af solen, som gjorde den til en gave til menneskene og gav sin billigelse til dens mangfoldiggørelse og vækst. Rodfrugterne, derimod, er måneplanter, hvis vækstcyklus beherskes af nattehimmellegemets fasekredsløb. De første sås af mænd, de sidste plantes af kvinder, men alle kulturplanter er komplementære og tjener til at opretholde en ligevægt i ernæringen alt efter produktionscyklens differentierede forløb.

Også dyrene klassificeres i overensstemmelse med de parametre, som omspænder den universelle orden og det sociale system. Slangen er knyttet til de dødes verden, mørket, regnen og frugtbarheden. I Dresdenkodeksen optræder den adskillige gange som udsmykning på Ixchels kappe, hovmodigt sammenrullet om dennes hår. Myren er et dyr, der knyttes til solen, som den hjalp med at trække majsen ud af dens skjul. Skønt myren er i stand til at bryde igennem den underjordiske verden, forbliver den alligevel et jorddyr, både menneskets forbundsfælle og rival i udnyttelsen af kornets kerner.

Mayaerne på Yucatan fortolker måneformørkelser som en myres forsøg på at bide 
himmellegemet i ansigtet, mens størstedelen af de andre mayatalende samfund forklarer måneformørkelsen som et slagsmål eller et skænderi, hvor Solen og Månen sætter sig op mod hinanden som en følge af sidstnævntes utroskab. Myren knyttes altså sammen med solprincippet og dens sammenstød med Månen understreger blot de stridigheder, som periodisk modstiller det kosmiske pars halvdele.

\section{Liv og død}

Solen er symbolet på liv og håb, men også det himmellegeme, som bærer på truslen om universets apokalyptiske ødelæggelse. Ligesom månen, der knyttes sammen med åndeverdenen i underverdenen, med fødslens dødsfarer og dødens tusmørkekomme, også er beskytterinden ved barsel, menneskets livsvæverske og kilde til planternes frugtbarhed. Skiftevis forenede og adskilte i livs- og dødskredsløbene veksler sol og måne med hinanden for at sikre universets fornyelse, og i ritualerne bæres vidne om denne uopløselige komplementaritet. Månen er billedet på det fuldstændige, det stabile og bestandige. Fordi den dagligt forbinder lyset og mørket og livet og døden, implicerer den en forestilling om fylde: månen sammenbinder de to dele af et kosmisk system, der trues af evig ikke-orden - den er helhedens billede. Dens sedentære karakter gør den til den faste grund under et system, der graviterer omkring månens figur. Selv solen dør og genfødes, mens månen aldrig hører op med at leve og, måned efter måned, at føde menneskelivets fosterkim.

Den kosmiske ligevægt i lakandonernes univers vipper omkring bipolariteten mandkvinde, der tjener som fysisk støtte for en komplet serie symbolske forestillinger, som selv er organiseret $\mathrm{i}$ form af paradigmatiske par. Undersøgelsen af homologien mellem de principper, som træder frem på baggrund af dette system af forbindelser, lader en særlig logik træde frem - logikken i det sociale system, som grunder sig på den kategorielle modsætning ældre-yngre. Men disse modsætninger, som får begreberne symmetri og hierarki til at intervenere, strukturerer også den mytiske tænkning. Der findes altså en slående parallelisme mellem de former, forestillingen om den ideale verden antager, og de former, den reelle verden er organiseret efter, og denne parallelisme fremstiller den markante betydning af et dualistisk begrebssystem, der anvendes til at skabe og derefter reproducere et socialt univers, som er tilpasset tankens fordringer.

Oversat af Kennet Pedersen 


\section{Noter}

1. Lakandonerne i Chiapas, mayatalende indianere i den sydlige tropiske regnskov i Mexico, betegner sig selv med denne term: „Hach Winik“.

2. Ordret: „Nuestro Verdadero Señor“, universets og menneskenes skabergud hos nordlakandonerne. Hans modsvarighed hos sydlakandonerne er: Ich Chan Yum, ordret: „Nuestro Pequeño Señor “. Han er den sidstfødte af de tre brødre, som danner den guddommelige trehed af herrer over lakandonsk tid og rum.

3. Zukunkyum (Hach Ak Yums ældre broder) er ansvarlig for solens hvile og for at bringe ham til verdens østkant ved daggry, så han kan genoptage sin daglige bevægelse over himlen.

4. Se Boremanse 1986:188.

5. Se Marion 1992.

6. K'in: sol; Ich: ansigt eller øje; Ahau: herre. En yukatekisk mayaguddom, som forbindes med solen, hed Kinich Ahau: solansigt eller herre med soløjet (Thompson 1975:289).

7. Den store månegudinde.

8. Denne myte er en sammenfatning af de oplysninger, Boremanse har indsamlet, og dem, der er publiceret af Bruce (1974:63-67) og Cline (u.å.).

9. Forf. anm: Bucida buceras, et tropisk træ, der blomstrer i maj.

10. Forf. anm: Et (ikke-identificeret) tropisk træ, som blomstrer i august, når regnfaldene er allermest vandfyldte.

11. Forf. anm: De kraftige regnskyl fra oktober til november.

12. Vogter af de dødes underjordiske land og regnfaldenes herre.

13. Itzam: leguan; Na': hus, altså Leguanens hus. Denne store klassiske mayagud fortolkes blandt arkæologer som havende været universets skaber. Han blev fremstillet med en øgleagtig krop, hvorpå verden mentes at hvile. Forskellige versioner af dette mellemamerikanske, halvt himmelske og halvt ktoniske, ur-uhyre viser, at denne kosmogoniske fortolkning af jordens oprindelse har været fælles for alle førkolumbianske kulturer. Se Graulich (1987), Soustelle (1986) og Thompson (1975).

14. Jf. Thompson (1975:257).

15. Citeret fra Thompson (1975:258).

16. Brosimum alicastrum eller Trophis racemosa, som man anvender i stedet for majs, når der er kornmangel. Maya: Ox, eller: Hach ox; spansk: ramon.

17. Yukatetisk: X-Kan Le Ox: femininum-gul-løv-brødtræ.

18. Cogolludo (1867-68), citeret fra Thompson (1975:258).

19. Aulie (1951), citeret fra Thompson (1975:306-7).

20. I mayakosmologien forbindes rød med øst, hvid med nord, sort med vest og gul med syd.

21. Thompson (1975:257). I mellemamerikansk tænkning forbindes nord med underverdenen, Mictlan (Duverger 1979:125), med natten og regntiden (Graulich: personlig meddelelse 1992).

22. Chilam Balam de Chumayel:165.

23. Jf. Lévi-Strauss (1991:269).

24. Jf. Lévi-Strauss (1991:269, 244). 
25. Jf. Lévi-Strauss (1991:224).

26. Se nærmere Thompson (1975:297-337)

27. Mere indgående i Marion (1992), kapitlerne 5, 7 og 8.

28. Klimatiske, atmosfæriske, meteorologiske og økologiske.

29. I denne myte, som Thompson har syntetiseret, er solen den anden af tre brødre. Venus er den ældste, og den mindste broder, som straks forvandles til en abe af sine brødre, bliver til natstjernen. Sol gifter sig med Måne; efter at hustruen har begået dobbelt hor, redder parret sig fra at blive brændt på et bål, for derpå at stige op på himlen og slå sig ned dér.

30. Ah: et præfiks, der angiver maskulinum, mens Ix (eller: $\mathrm{X}$-) angiver femininum.

31. I mellemamerikansk mytologi blev syd forbundet med middag og tørtid, altså varme, mens nord blev forbundet med midnat, regntid og kulde (Graulich: personlig meddelelse 1992).

32. I mayaernes billedfremstillinger er tegnet for dynastisk magt en ceremoniel, øst-vest-orienteret stok, hvis yderpunkter dannes af slangegab. Man har identificeret dette emblem som symbol for det at bære verden.

33. Jf. Perrin (1976:166). Hvad angår mayaerne, har det i særlig grad været referencer til farver og til de udtryk, farverne hentyder til, som har været afkodningsmidler over for det esoteriske sprog, der jo i overvejende grad anvendes ved rituelle bønfaldelser.

34. Mens solen beskrives ved den position, den indtager under sin gang over himlen (Tan u okor $\mathrm{K}$ 'in: solen går ud; $\tan \mathrm{u}$ chumuk ka K'in: solen er i midten, dvs. zenit; tan u bin K'in: solen går bort), identificeres månen efter sine faser, og det vil sige efter sin fremtrædelsesmåde, figur og form (tan u chiir $\mathrm{Ak} \mathrm{Na}^{\prime}$ : Vor moder er ved at blive tyk; Ne tarak u bak Ak Na': Vor moder er tyk, det vil sige fuld; Muulik Na': Vor moder er slank; osv.) - for når den aftager og senere forsvinder, skjuler den sig på småøer (muulik na'), som udgør tilflugtssteder af land $i$ et univers af vand.

35. Dette træk, husker vi, tilskrives månen i andre mellemamerikanske kulturer — som anført af Graulich $(1987: 128)$

36. Graulich (personlig meddelelse).

37. Jf. Galinier (1985:968).

38. Jf. Galinier (1985:968).

39. Se Thompson (1939:169-70) og Graulich (1987).

40. Mere indgående i Marion 1992, kapitel 2.

\section{Litteratur}

Aulie, W. \& E. Aulie

1951 Palencano-Chol Vocabulary and Folk-tales with English Translation. Manuskript.

Boremanse, Didier

1986 Contes et mythologie des Indiens lacandons. Paris: L'harmattan.

Bruce, Robert

1974 El Libro de Chank'in. Mexico: INAH.

Chilam Balam de Chumayel

1979 Forord og oversættelse ved Antonio Mediz Bello. Mexico: UNAM.

Cline, Herbert

u.å. $\quad$ Lore and Deities of the Lacandon Indians, Chiapas, Mexico.

Journal of American Folklore 57:224. 
Duverger, Christian

1979 La fleur letale: l'économie du sacrifice chez les Aztèques. Paris: Seuil.

Galinier, Jacques

1985 Le moitié du monde. Thêse de Doctorat. Paris: EHESS.

Graulich, Michel

1987 Mythes et rituel du Mexique ancien préhispanique. Bruxelles: Académie Royale de Belgique.

Lévi-Strauss, Claude

$1991 \quad$ Histoire de Lynx. Paris: Plon.

Lopez de Cogolludo

1867-68 Historia de Yucatan, escrita en el siglo XVII. Mérida.

Marion, Marie-Odile

1992 Le Pouvoir de filles de Lune: la dimension symbolique des formes d'organisation sociale des Lacandon du fleuve Lacanjá, Mexique. Thêse de Doctorat. Paris: EHESS.

Perrin, Michel

1976 Le chemin des Indiens morts. Paris: Payot.

Scheele, Linda \& David Freidel

1990 A Forest of Kings: The Untold Story of the Ancient Maya. New York:

W. Morrow and Company.

Soustelle, Jacques

1986 L'univers des Aztèques. Paris: Hermann.

Thompson, John Eric

1939 The Moon Goddess in Middle America, with Notes on Related Deities. Carnegie Institution of Washington, Publication 509.

1975 Historia y religión de los Mayas. Mexico: Siglo XXI. 
